\title{
Characterising the Coffee-Banana Agroforestry Systems: an Entry Point for Promoting Coffee and Banana Growing in mid-Northern Uganda
}

\author{
H.G. Kagezi ${ }^{*,}{ }^{1}$, P. Kucel ${ }^{1}$, J. Kobusinge ${ }^{1}$, L. Nakibuule ${ }^{1}$, F. Akwatulira ${ }^{1}$, I. Perfecto ${ }^{2}$, W.W. \\ Wagoire ${ }^{1}$ \\ ${ }^{1}$ National Coffee Research Institute (NaCORI). ${ }^{2}$ University of Michigan. \\ *Corresponding author. $\square 185$ Mukono, Uganda@gkagezi@gmail.com
}

\begin{abstract}
This study was conducted in the mid-Northern Ugandan districts of Nwoya, Gulu, Lira, Apach and Oyam to characterise the coffee-banana agroforestry systems. Thirty fields with coffee-banana agroforestry systems were selected and the level of field and crop management determined. Additionally, five coffee and banana plants were randomly selected and assessed for pests and diseases. All fields had Robusta coffee type whereas cooking bananas were the dominant clone (45\%). Field management was limited. More than $80 \%$ of the fields had no bands, trenches or cover-crops. Most of the fields were lowly weeded (46.7\%) and mulched $(60 \%)$. Intercropping was low with $20 \%$ having maize or cassava. Similarly, most fields were lowly inter-planted with trees $(40 \%)$ with only 28 tree/shrub species and dominated by fruit trees; namely oranges $(70 \%)$, mangoes $(63.3 \%)$ and pawpaw $(56.7 \%)$ of the total number of tree species observed in the systems. Generally, $40 \%$ of coffee fields had not been de-suckered, pruned or changed cycle. However, at least $35 \%$ of the coffee fields were highly pruned and their cycle changed. For bananas, more than $70 \%$ of the fields were not de-suckered, propped or their corms removed, but $63 \%$ of them had been de-leafed and de-budded at a low to moderate level. Leaf skeletonisers and coffee leaf rust were the most observed pest $(77.3 \%)$ and disease $(15.3 \%)$ respectively. Pest damage was limited in bananas, though black Sigatoka was the commonest disease observed (56\%). It is concluded that the region has embraced the systems but there is need for farmers to be provided with the right species of coffee, banana and trees.
\end{abstract}

Keywords: Agroforestry-systems, cooking-bananas, Robusta-coffee.

\section{INTRODUCTION}

Coffee (both robusta and arabica) is the most important cash crop of Uganda, playing a vital part in the country's economy and livelihoods of its people (Musoli et al., 2001). It contributes more than $3 \%$ of the Gross Domestic Product (GDP) and 18-20\% of annual foreign exchange earnings valued at US $\$ 370$ million in the coffee year 2015/16 (UCDA, 2016). The crop is grown by over 1.3 million smallholder households and provides employment to over 5 million
Ugandans, through coffee-related activities along the value chain (Hill, 2005). In Uganda, coffee is traditionally grown in the central, western and eastern regions (Musoli et al., 2001). However, the Government is aiming at accelerating coffee production from 3.74 million $60 \mathrm{~kg}$ bags in 2014/15 to 20 million $60 \mathrm{~kg}$ bags by 2020 , through a number of strategies; including promotion of the crop in non-traditional growing regions particularly in the northern region (Mbowa et al., 2014). Intense efforts by the 
Uganda Coffee Development Authority (UCDA) are currently underway to distribute coffee planting materials to farmers in the region (UCDA, 2016).

Production of coffee in Uganda is mainly rain-fed (Mwaura and Katunze, 2014), making it vulnerable to climate variability (Mubiru et al., 2012). This is more pronounced in marginal areas like northern Uganda, with a lengthy dry spell of 4-5 months (Mbowa et al., 2014). This restrains coffee production to one season of the year instead of two seasons as in the traditional coffee growing regions like central Uganda (Mbowa et al., 2014). It also dictates that the crop is grown under shaded conditions (Beer, 1987). Shade could be provided by bananas (Oduol and Aluma 1990; van Asten et al., 2011) and/or trees (Kiyinji and Gwali, 2012; Bukomeko et al., 2015). These coffeebanana agroforestry systems, therefore, present an opportunity for improving household income and food security, as well as mitigation for climatic adversities northern Uganda (Okorio et al., 2004). The objective of this study was to characterise the coffee-banana agroforestry systems of mid-northern Uganda.

\section{MATERIALS AND METHODS}

\section{Study Location}

The study was conducted in five districts located in the mid-northern coffee growing sub-region; namely, Acholi sub-region (Gulu and Nwoya district) and Lango subregion (Lira, Apac and Oyam districts). Acholi sub-region lies at 412"N, 1०29"S and $29^{\circ} 34^{\prime \prime} \mathrm{E}, 35^{\circ} 0^{\prime} \mathrm{N}$, with temperature range of $15-32^{\circ} \mathrm{C}$. The sub-region has a generally flat topography, with predominantly sandy loam soils. It receives
800-1500 mm of rain per annum with a bimodal rainfall pattern from March to June ( $1^{\text {st }}$ season) and July to November ( $2^{\text {nd }}$ season; UITWG, 2014). On the other hand, the Lango sub-region lies between $2^{\circ} 17^{\prime}$ $60.00^{\prime \prime} \mathrm{N}$ and $33^{\circ} 00^{\prime} 0.00^{\prime \prime} \mathrm{E}$. It receives about $1000-1500 \mathrm{~mm}$ of rainfall per annum with temperatures of $25-35^{\circ} \mathrm{C}$ (Okwir, 2009).

\section{Sample Farm Selection, Data Collection and Analysis}

A total of 30 households practicing coffeebanana agroforestry systems were purposively selected for the study. In each sampled plot, a $25 \mathrm{~m} \times 25 \mathrm{~m}$ transect was mapped out and data taken on the intensity of field and crop management of both coffee and bananas. In addition, 5 coffee plants and 5 banana mats were chosen randomly within the transect and scored for pests and diseases. For data analysis, descriptive statistics were used to obtain means, standard deviations and frequencies using Statistical Analysis System (SAS) software (SAS Institute, 2008).

\section{RESULTS}

\section{Coffee Types and Banana Clones}

Table 1 shows the coffee types and banana clones observed in the coffee-banana agroforestry systems of mid-northern Uganda. All the sampled fields had Robusta coffee, which was dominated by the clonal type $(76.7 \%)$. On the other hand, the banana clones observed were dominated by the East African Highland Bananas (EAHB's), locally called 'Matooke' (45\%), Pisang Awak (Kayinja, 22\%) and Apple banana (sukali ndiizi, 18\%). 
Table 1. Coffee types and banana clones observed

\begin{tabular}{lll}
\hline Type/ clone & Use & Fields (\%) \\
\hline Coffee & & \\
Clonal & Income & 76.7 \\
Elite & Income & 23.3 \\
Banana & & \\
East African Highland Bananas (Matooke) & Cooking & 45.3 \\
Pisang Awak (kayinja) & Beer & 22.3 \\
Apple banana (sukali ndiizi) & Dessert & 17.8 \\
FHIA 17 & Dessert & 5.6 \\
Bloggue (kivuvu) & Dessert & 5.6 \\
Gros Michel (bogoya) & Dessert & 1.7 \\
Yangambi-Km5 & Dessert & 1.0 \\
Kisubi & Beer & 0.7 \\
\hline
\end{tabular}

\section{Trees/ Shrub Species}

Most of the fields were lowly inter-planted with trees/shrubs (40\%; Figure 1). Only 28 tree/shrub species were observed in the coffee-banana agroforestry systems. These were dominated by fruit trees, oranges $(70 \%)$, mangoes $(63 \%)$ and papaya $(57 \%$, Table 2).

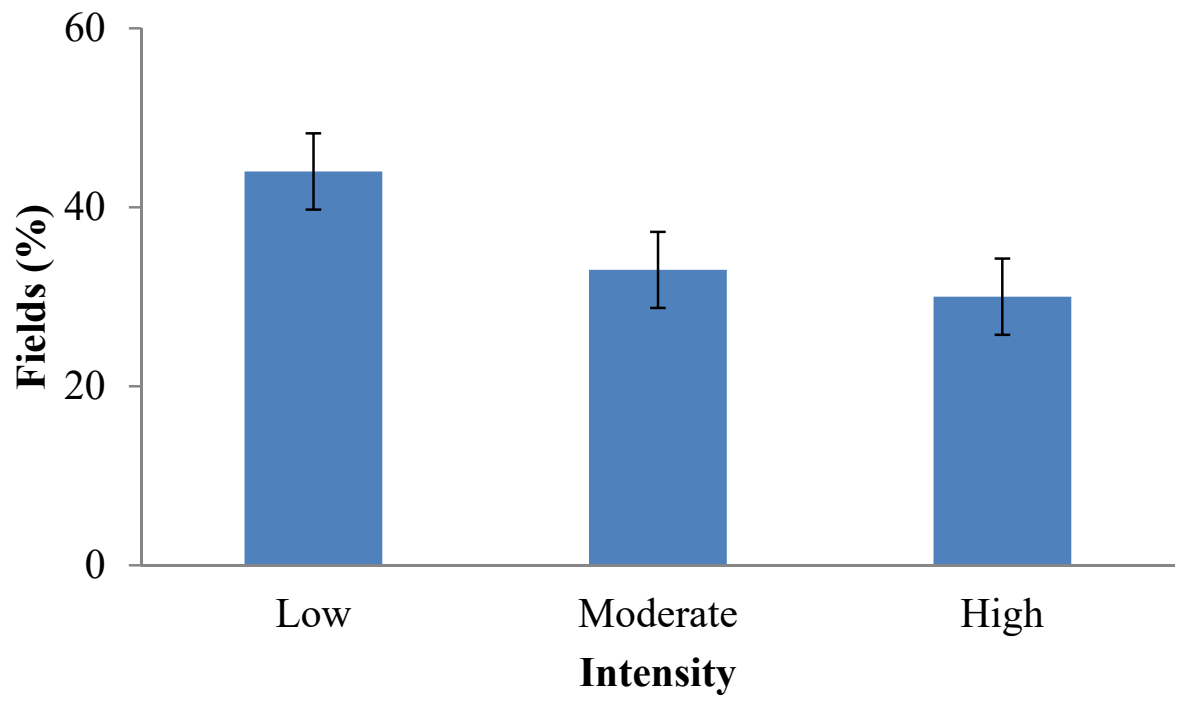

Figure 1. Intensity of inter-planting with trees/shrubs observed in the in the mid-northern Uganda coffee-banana agroforestry systems 
Table 2. Tree/ shrub species observed

\begin{tabular}{llll}
\hline Family & Common name & Scientific name & Fields (\%) \\
\hline Rutaceae & Orange & Citrus sinensis & 70.0 \\
Anacardiaceae & Mango & Mangifera indica & 63.3 \\
Caricaceae & Papaya & Carica papaya & 56.7 \\
Fabaceae & & Albizia coriaria & 46.7 \\
Moraceae & Jack fruit & Artocarpus heterophyllus & 40.0 \\
Moraceae & Natal fig & Ficus natalensis & 36.7 \\
Lauraceae & Avocado & Persea americana & 33.3 \\
Arecaceae & Borassus palm & Borassus spp & 33.3 \\
Caesalpinioideae & Cassia & Senna spectabilis & 33.3 \\
Boraginaceae & Large-leaved cordia & Cordia africana & 33.3 \\
Myrtaceae & Guava & Psidium guajava & 33.3 \\
Bignonaceae & Nile tulip tree & Markhamia lutea & 30.0 \\
Asteraceae & Bitter leaf & Vernonia amygdalina & 30.0 \\
Rhamnaceae & Umbrella tree & Maesopsis eminii & 26.7 \\
Annonaceae & Soursop & Annona muricata & 23.3 \\
Moraceae & Rock-elm & Milicia excels & 20.0 \\
Fabaceae & West African Albizia & Albizia zygia & 20.0 \\
Rosaceae & Red stinkwood & Prunus africana & 16.7 \\
Moraceae & Sandpaper tree & Ficus exasperata & 16.7 \\
Moringaceae & Moringa & Moringa oleifera & 16.7 \\
Rutaceae & Tangerine & Citrus tangerina & 16.7 \\
Proteaceae & Silky oak & Grevillea robusta & 13.3 \\
Meliaceae & Neem tree & Azadirachta indica & 13.3 \\
Myrtaceae & Eucalyptus & Eucalyptus spp. & 10.0 \\
Myrtaceae & Black plum & Syzygium cumini & 10.0 \\
Bignoniaceae & African tulip tree & Spathodea campanulata & 10.0 \\
Moraceae & Sycamore fig & Ficus sycomorous & 10.0 \\
Lamiaceae & Teak & Tectona grandis & 10.0 \\
\hline
\end{tabular}

\section{Field Management Practices}

Field management practices observed in the study area are summarised in Table 3. Most of the fields were poorly managed, with more than $80 \%$ of them having no manure, bands, trenches nor cover-crops. Also, most of the fields were lowly weeded $(46.7 \%)$ and mulched (60\%). Intercropping was generally lowly practiced (Figure 2), with 20\% having maize or cassava (Table 4).

Table 3. Intensity of field management practices observed

\begin{tabular}{lllll}
\hline \multirow{2}{*}{ Management practice } & \multicolumn{3}{c}{ Intensity of practice } & \\
& Not practicing & Low & Moderate & High \\
\hline Weeding & 6.7 & 46.7 & 40.0 & 6.7 \\
Mulching & 23.3 & 60.0 & 16.7 & 0.0 \\
Manuring & 90.0 & 6.7 & 3.3 & 0.0 \\
Bands & 96.7 & 3.3 & 0.0 & 0.0 \\
Cover crops & 83.3 & 13.3 & 3.3 & 0.0 \\
Trenches & 86.7 & 10.0 & 3.3 & 0.0 \\
\hline
\end{tabular}

Low $=1-25 \%$; Moderate $=26-50 \%$; High $=>50 \%$ 


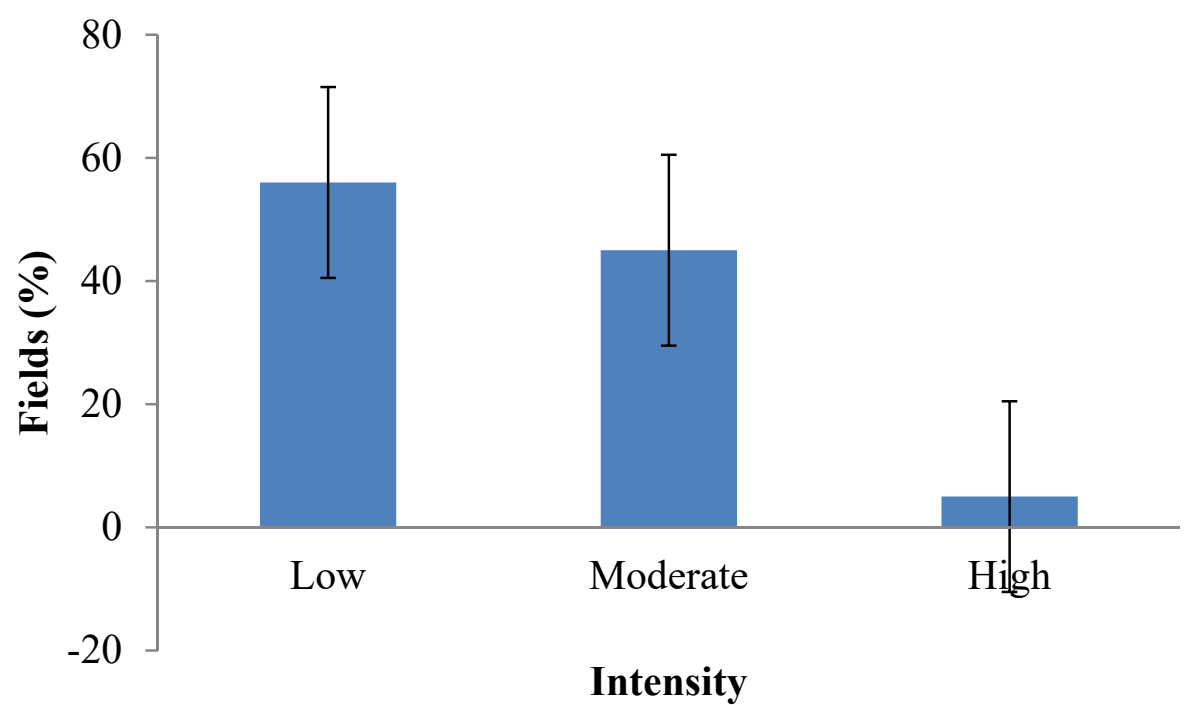

Figure 2. Intensity of inter-cropping observed

Table 4. Inter-crops in the region

\begin{tabular}{lll}
\hline Crop & Scientific name & Fields (\%) \\
\hline Cassava & Manihot esculenta & 20.0 \\
Maize & Zea mays & 20.0 \\
Cocoa & Theobroma cacao L. & 16.7 \\
Coco yams & Colocasia esculenta & 16.7 \\
Green vegetables & Amarathus spp & 10.0 \\
Beans & Phaseolus vulgaris & 6.7 \\
Tomatoes & Solanum lycopersicum & 6.7 \\
Groundnuts & Arachis hypogaea & 6.7 \\
Pineapple & Ananas comosus & 6.7 \\
Pumpkins & Cucurbita pepo & 6.7 \\
Cabbages & Brassica oleracea var. capitata & 3.3 \\
Cow peas & Vigna unguiculata & 3.3 \\
Eggplants & Solanum melongena & 3.3 \\
Millet & Pennisetum glaucum & 3.3 \\
Soy beans & Glycine max & 3.3 \\
Pigeon peas & Cajanus cajan & 3.3 \\
Bitter tomato & Solanaceous aethiopicum & 3.3 \\
Sesame & Sesamum indicum & 3.3 \\
\hline
\end{tabular}

\section{Crop Management Practices}

Crop management, at plant level was also poor (Table 5). Generally, $40 \%$ of coffee fields had not been de-suckered, pruned or their cycle changed. However, at least 35\% of the coffee fields were highly pruned and their cycle changed. On the other hand, more than $65 \%$ of the bananas had not been de-suckered, propped nor their corms removed, but, $63 \%$ of them had been deleafed and de-budded at a low to moderate level. 
Table 5. Intensity of crop management practices observed

\begin{tabular}{lllll}
\hline Management practice & \multicolumn{4}{c}{ Intensity of practice } \\
& Not practicing & Low & Medium & High \\
\hline Coffee & & & & \\
De-suckering & 40.0 & 16.7 & 20.0 & 23.3 \\
Pruning & 46.7 & 3.3 & 13.3 & 36.7 \\
Change of cycle & 40.0 & 3.3 & 16.7 & 40.0 \\
Bananas & & & & \\
De-suckering & 70.0 & 16.7 & 6.7 & 6.7 \\
De-leafing & 20.0 & 33.3 & 30.0 & 16.7 \\
De-budding & 20.0 & 33.3 & 30.0 & 16.7 \\
Corm removal & 93.3 & 6.7 & 0.0 & 0.0 \\
Propping & 80.0 & 16.7 & 3.3 & 0.0 \\
\hline
\end{tabular}

Low $=1-25 \%$; Moderate $=26-50 \% ;$ High $=>50 \%$

Pests and diseases of coffee and bananas

Coffee was infested by a number of pests, with the most commonly observed being: leaf skeletonisers $(77 \%)$, tailed caterpillars (58\%), coffee berry borer (33\%) and leaf eating beetles $(32 \%)$. Disease incidence on coffee was generally low, with the most common diseases being coffee leaf rust
$(15 \%)$ and red blister disease $(7 \%$, (Table 6$)$. On the other hand, pest damage was rarely observed on bananas, though, black Sigatoka was the commonest disease observed (56\% Table 7). However, this study did not assess pests and diseases for the trees/shrubs.

Table 6. Pests and diseases observed

\begin{tabular}{lll}
\hline Constraint & Scientific name & Coffee trees (\%) \\
\hline Pest & & \\
Leaf sketeltonisers & Leucoplema dohertyi Warren & 77.3 \\
Tailed caterpillars & Epicampotera spp & 55.7 \\
Coffee berry borer & Hypothenemus hampei & 33.3 \\
Leaf eating beetles & & 32.3 \\
Leaf miners & Leucoptera coffeina & 21.0 \\
Weaver ants & Oecophylla smaragdina & 8.7 \\
Coffee berry moth & Prophantis smaragdina (Butler) & 8.0 \\
Spider mites & Olygonychus spp & 0.3 \\
Mealybugs & Planococcus spp & 0.3 \\
Termites & Odontotermes spp & 0.3 \\
Disease & & \\
Coffee leaf rust & Hemileia vastatrix & 15.3 \\
Red blister disease & Cercospora coffeicola & 6.7 \\
Brown eye spot & Cercospora coffeicola & 0.3 \\
Coffee Wilt Disease & Gibberella xylarioides (Fusarium xylarioides) & 0.3 \\
\hline
\end{tabular}


Table 7. Diseases observed on bananas

\begin{tabular}{lll}
\hline Common name & Scientific name & Mats (\%) \\
\hline Black sigatoka & Mycosphaerella musicola (Mulder) & 56.0 \\
Fusarium wilt & Fusarium oxysporum & 4.0 \\
Banana xanthomonas wilt & Xanthomonas campestris pv. musacearum & 3.5 \\
\hline
\end{tabular}

\section{DISCUSSION}

\section{Coffee Types and Banana Clones}

Our study showed that all the sampled households were growing Robusta coffee, Coffea canephora (Table 1). The reason for this is that the mid-northern region is situated below 1400 m below sea level (Okwir, 2009; UITWG, 2014), therefore suitable for growing this type of coffee (Musoli et al., 2001). Most of the Robusta coffee observed was of the clonal type because the Uganda Coffee Development Authority (UCDA) has been promoting this type of coffee for some time (Mbowa et al., 2014). On the other hand, the East African Highland Bananas (EAHB), commonly known as 'Matooke' dominated the banana clones observed in the region (Table 1). This could be attributed to NARO/NARL's efforts of promoting and distributing banana planting materials of this type of bananas in the region (Kubiriba et al., 2016). Bananas have additional advantages of yielding throughout the year and needing less investment compared to other crops (Nyombi, 2013). Additionally, bananas are a source of shade to coffee when it is still young (van Asten et al., 2011). However, the region needs suitable banana cultivars such as Kiwangaazi (a motooke hybrid) and the FHIA's - these cultivars can resist drought as well as pests and diseases (Nowakunda and Tushemereire, 2004; Tinzaara et al., 2009).

\section{Trees/ Shrub Species}

A total of 28 tree/shrub species were observed in all the study fields (Table 2) and less than the 40, Ssebulime (2017) observed in the banana agroforestry systems of central Uganda. These tree/shrub species were dominated by fruit trees particularly oranges, mangoes and papaya (Agea et al., 2010; Oryema et al., 2013). Similarly, Ssebulime (2017) reported mangoes, Mangifera indica as one of the commonest trees/shrubs in banana agroforestry systems of central Uganda. The research challenge is therefore, finding the best-bet fruit trees that are compatible with both food and cash crops and which are less competitive but at the same time offering maximum soil fertility (Ssebulime et al., 2017). However, basing on farmers' preference and scientific knowledge, NARO/NaCORI has identified and recommended three site-specific shade tree species (Ficus natalensis, Albizia coriaria and Cordia Africana) for inter-planting in the coffee-banana systems of this region (Kagezi et al., 2016a). These coffee-banana agroforestry systems therefore present an opportunity for improving household income and food security, as well as mitigation for climatic adversities in the region (Okorio et al., 2004).

\section{Field Management Practices}

Management of the coffee-banana agroforestry fields was poor - with $>80 \%$ of them with no manure, bands, trenches nor cover-crops, at the same time, lowly weeded $(46.7 \%)$ and mulched (60\%; table 3). Other practices like intercropping were lowly practiced (Fig. 1) - with 20\% having maize or cassava (Table 4). The reason for this is in part due to the fact that both crops are not traditional in this region, implying that 
farmers are just acquiring knowledge and skills of managing these biotic stresses (Mbowa et al., 2014).

\section{Crop Management Practices}

The coffee plants were also generally poorly managed. Most of the coffee fields $(40 \%)$ were not been de-suckered, pruned or their cycle changed whereas, $>65 \%$ of the bananas had not been de-suckered, propped nor their corms removed. Low knowledge on the good agricultural practices (GAP's) has been identified as one of biggest challenges to coffee and banana production in northern Uganda (Zeweldu, 2014) and elsewhere (Wairegi et al., 2010; Okech et al., 2004). This problem is exacerbated by the limited availability of specialised coffee and banana extension support (Mbowa et al., 2014).

\section{Pests and Diseases of Coffee and Bananas}

Leaf skeletonizers, Epiplema dohertyi Warren (Lepidoptera: Epiplemidae) and the tailed caterpillars, Epicampoptera sp. (Lepidoptera: Erebidae) were the commonest insect pests observed in the mid-northern Uganda coffee-banana agroforestry system (Table 6). This agrees with studies in coffee-banana agroforestry systems in other regions of Uganda (Kagezi et al., 2016b; Kobusinge, 2016) as well as other coffee systems in lower altitudes (Musoli et al., 2001; Jassogne et al., 2013). These insect pests feed on coffee leaves, reducing the photosynthetic area and thus the yield of the attacked coffee tree (Wrigley, 1988; Rutherford and Phiri, 2006). The high incidence of both these pests is the region is in part be due to farmers' lack of knowledge of the damage these pests cause as well as their management options (Kagezi et al., 2016b; Kobusinge, 2016).

For the diseases, coffee leaf rust was the most commonly observed on coffee in the region. The disease is caused by a fungus,
Hemileia vastatrix (Berkeley and Broome) and has been recognised to be important in Robusta coffee-banana agroforestry systems of other studied region (Kagezi et al., 2016b; Kobusinge, 2016), as well as on Arabica coffee (Musoli et al., 2001; Rutherford and Phiri, 2006). Severe cases of the disease cause serious defoliation that reduces the photosynthetic area and in turn, yields (Rutherford and Phiri, 2006). On the other hand, pest damage on bananas was rarely observed (Table 6). Similarly, low pest pressure was observed in coffee-banana agroforestry systems in other regions of Uganda (Kagezi et al., 2016b; Kobusinge, 2016). The reasons for the low damage by the banana weevil, Cosmopolites sordidus (Germar), the most important insect pest of bananas are yet to be given. High damage by this insect pest is associated with extended droughts (Gold et al., 2001), a common phenomenon the study area. Nevertheless, black Sigatoka was the commonest disease observed, agreeing with studies in coffeebanana agroforestry systems in other regions of Uganda (Kagezi et al., 2016b; Kobusinge, 2016). This disease is caused by the fungus Mycosphaerella fijiensis and leads to serious yield reduction on bananas, particularly the EAHB's (Tushemereirwe, 1996; Tushemereirwe et al., 2004). The high incidence of the disease in the region could therefore be in part due to the fact that most of the banana clones observed belonged to the susceptible EAHB's. This is coupled with farmers' lack of knowledge of the banana diseases as well as their management. Black sigatoka causes premature drying of leaves and thus reducing the functional leaf area resulting into incomplete filling of banana fingers and yield loss (Tushemereirwe et al., 2004).

Nevertheless, the agroforestry systems have been reported to manage certain pests and diseases in coffee and other crops (Beer et al., 1998; Tscharntke et al., 2011; Pumariño et al., 2015). Research should therefore gear more efforts towards optimising these 
coffee-banana agroforestry systems for managing pests and diseases (Kobusinge et al., 2016; Kobusinge, 2017).

\section{Conclusion}

In conclusion, Robusta coffee and the East African Highland Bananas (EAHB's) were the major coffee and banana types grown in the coffee-banana agroforestry systems of mid-northern Uganda respectively. Only 28 tree/shrub species were observed in the systems and dominated by fruit trees. Management at both field and crop level including pests and diseases was poor. Therefore, research and extension should put more efforts in farmer awareness as well as optimising these systems for managing pests and diseases of both crops.

\section{Acknowledgement}

This research was supported by funds from PEER-USAID. The authors also thank Uganda Coffee Development Authority (UCDA) extension officers, and farmers of mid-northern Uganda coffee-banana agroforestry systems who participated in the study.

\section{REFERENCES}

Agea, J.G., Obua, J., Waiswa, D., Okia, C.A., and Okullo, J.B.L. 2010. Farmers' attitudes towards on-farm cultivation of indigenous fruit trees in Adwari SubCounty, Lira district, Uganda. Ethnobotanical Leaflets 14: 366-380.

Beer, J., Muschler, R., Kass, D. and Somarriba, E. 1998. Shade management in coffee and cacao plantations. Agroforestry Systems 38:134-164.

Bukomeko, H., Jassogne, L., Mawanda, A., Senyonjo, D. and Mukasa, D. 2015. Functional suitability of trees in coffee shade systems in different precipitation zones of Central Uganda. Technical Report. July 2015.
Gold, C.S., Pena, J.E. and Karamura, E.B. 2001. Biology and integrated pest management for the banana weevil Cosmopolites sordidus (Germar) (Coleoptera: Curculionidae). Integrated Pest Management Reviews 6:79-155.

Hill, R.V. 2005. Risk, production and poverty: A study of coffee in Uganda. D. Phil thesis, University of Oxford.

Jassogne, L., Läderach, P. and van Asten, P., 2013. The impact of climate change on coffee in Uganda: Lessons from a case study in the Ruwenzori Mountains. Oxfam Research Reports.

Kagezi, G.H., Kucel, P., Nakibuule, L., Kobusinge, J. and Wagoire, W.W. 2016b. Sustainable coffee-banana agro-forestry systems to adapt to climate change, enhance food security and alleviate poverty in Uganda. End of project report. March 2016.

Kagezi, G.H., Musoli, P., Kucel, P., Nakibuule, L., Kobusige, J., Tumuhaise, V., Ahumuza, G., Akwatulira, F., Nalukenge, A., Magambo, B., Nuwagira, F., Olal, S., Aluka, P., Olango, N. and Wagoire, WW. 2016a. Recommended shade tree systems for the diverse coffee agro ecologies of Uganda. Training manual.

Kiyinji, I, and Gwali, S. 2012. Productivity and profitability of Robusta coffee agroforestry systems in central Uganda. Uganda Journal of Agricultural Sciences 13(1):85-93.

Kobusinge, J. 2016. Towards optimising coffee-banana agro-forestry cropping systems for management of biotic stresses in mid-eastern coffee growing region of Uganda. MSc. Thesis. Uganda Martyrs University Nkozi. November 2016.

Kubiriba, J., Ssali, R.T., Barekye, A., Akankwasa, K., Tushemereirwe, W.K., Batte, M., Karamura, E.B. and Karamura, D. 2016. The performance of East African highland bananas released in farmers' fields and the need for their 
further improvement. In: Proceedings. IX International Symposium on Banana: ISHS-ProMusa Symposium on Unravelling the Banana's Genomic Potential. (Smith, M. et al (Eds.)) Acta Horticulturae, 1114: p. 231-238. Leuven (Belgium), ISHS. ISBN: 978-94-6261108-5.

Mbowa, S., Odokonyero, T. and Munyambonera, E. 2014. The potential of coffee to uplift people out of poverty in Northern Uganda. EPRC Research Report No. 11.

Mubiru, D.N., Komutunga, E., Agona, A., Apok, A. and Ngara, T. 2012. Characterising agrometeorological climate risks and uncertainties: Crop production in Uganda. South African Journal of Science, 108(3-4):108-118.

Musoli, P.C., Hakiza, G.J., Birinkunzira, J.B., Kibirige-Sebunya, Kucel, P., 2001. Coffee (Coffea spp). In: Mukiibi, J.K. (Eds.), Agriculture in Uganda Vol. II. Fountain Publishers/CTA/NARO. pp. 376-436.

Mwaura, F. and Katunze, M. 2014. Enhancing agricultural production and productivity in Uganda through irrigation. Policy brief. Issue no. 49. September 2014. http://www.gwieastafrica.org/media/G WI_UgandaPolicy_Brief_NO_49.pdf.

Nowakunda, K. and Tushemereirwere, W. 2004. Farmer acceptance of introduced banana genotypes in Uganda. African Crop Science Journal 1:1-6.

Nyombi, K. 2013. Towards sustainable highland banana production in Uganda: opportunities and challenges. African Journal for Food, Agriculture, Nutrition and Development 13:7544-61.

Rutherford, M.A. and Phiri, N. 2006. Pests and diseases of coffee in eastern Africa: A technical and advisory manual. CAB International, Wallingford, U.K. https://agriskmanagementforum. org/sites/agriskmanagementforum.org/
files/Documents/U3071CoffeeManual. pdf. Last accessed on July 14, 2015.

SAS Institute Inc., 2008. SAS/STAT Users' Guide version 9.2, SAS Institute Inc., Cary, NC, USA.

Ssebulime, G., 2016. Canopy management, leaf fall, decomposition and termite assemblages in the banana agroforestry system of Kiboga district, Uganda. MSc thesis, Makerere University, Uganda.

Ssebulime, G., Kagezi H.G., Nyombi K., Mpiira S, Tushemereirwe, K.W., Karamura B.E. and Staver C. 2017. Termite assemblages in the banana agroforestry systems of Kiboga District, Central Uganda .International Journal of Agroforestry and Silviculture 4(3):267277.

Tinzaara, W., Kiggundu, A., Gold, C.S., Tushemereirwe, W.K. and Karamura, E.B. 2009. Management options for highland banana pests and diseases in East and Central Africa. Outlooks on Pest Management 20(5):204-208.

Tscharntke, T., Clough, Y., Bhagwat, S.A., Buchori, D., Faust, H., Hertel, D., Hölscher, D., Juhrbandt, J., Kessler, M., Perfecto, I., Scherber, C., Schroth, G., Veldkamp, E. and Wanger, T.C. 2011.Multifunctional shade-tree management in tropical agroforestry landscapes - a review. Journal of Applied Ecology 48:619-629.

Tushemereirwe, W.K. 1996. Factors Influencing Expression of Leaf Spot Diseases of Highland Bananas in Uganda. Ph.D. Thesis. University of Reading, Reading.

Tushemereirwe, W.K., Kangire, A., Kubiriba, J., Nakyanzi, M. and Gold, C.S. 2004. Diseases threatening banana biodiversity in Uganda. Journal of African Crop Science 12(1):19-26.

UCDA, 2016. Uganda Development Authority/Minister of Agriculture, Animal Industry and Fisheries. UCDA monthly report for April 2016. http://ugandacoffee.go.ug/ 
download/2009/ April-2016.pdf. Last accessed on September 28, 2016.

UITWG, 2014. Uganda IPC Technical Working Group. Report of the integrated food security phase classification analysis for Uganda. September 2014.

van Asten, PJA., Wairegi, LWI., Mukasa, D. and Uringi, NO. 2011. Agronomic and economic benefits of coffee-banana intercropping in Uganda's smallholder farming systems. Agricultural Systems 104(4): 326-334.
Wairegi, L.W.I., van Asten, P.J.A., Tenywa, M.M. and Bekunda, M.A. 2010. Abiotic constraints override biotic constraints in East African highland banana systems. Field Crops Research 117(1):146-153.

Zeweldu, T. 2014. Northern Uganda embraces banana growing to address food and income security. The East African Special Advertising Section, January 26, 2014. www.ipsos.co.ke/.../140126_The\%20Ea st $\% 20$ African $\% 20$ Special $\% 20$ Advertisin $\mathrm{g} \% 20$. 